\title{
Okul Öncesi Öğretmenlerinin Sanat ve Estetik Değerleri Kazandırma Öz Yeterlik Algılarının Íncelenmesi
}

\section{Examining Preschool Teachers' Self-Efficacy Perceptions in Helping Students Acquire Artistic and Aesthetic Values}

\author{
Salih AKYILDIZ, Sorumlu Yazar, Doç. Dr. \\ Trabzon Üniversitesi, Fatih Eğitim Fakültesi, Türkiye. \\ sakyildiz61@gmail.com \\ http://orcid.org/0000-0002-8569-7411
}

\section{ISSN: 1303-880X \\ e-ISSN: 2667-7504 \\ http://ded.dem.org.tr}

Makale Türü / Article Type: Araştırma Makalesi / Research Article Geliş Tarihi / Received Date: 09.10.2019 Kabul Tarihi / Accepted Date: 12.01.2020 Yayın Tarihi / Published Date: 25.06.2020 Tr/En: $\mathrm{Tr}$

Intihal / Plagiarism: Bu makale, en az iki hakem tarafindan incelendi ve intihal içermediği teyit edildi. / This article has been reviewed by at least two referees and scanned via a plagiarism software.
Atıf/Citation: Akyıldız, S. (2020). Okul öncesi öğretmenlerinin sanat ve estetik değerleri kazandırma öz yeterlik algılarının incelenmesi. Değerler Eğitimi Dergisi,18(39), s.209-234. https://doi.org/10.34234/ded.629922 
Öz: Bu araştırmanın amacı, okul öncesi öğretmenlerinin sanat ve estetik değerlerin kazandırılması ile ilgili öz yeterlik algılarını belirlemek ve yeterlik algılarının bazı değişkenlere göre değişip değişmediğini incelemektir. Araştırma tarama modeline dayalı olarak yürütülmüştür. Araştırmanın evreni, Trabzon il ve ilçe merkezlerindeki okullarda görev yapan 646 okul öncesi öğretmeninden oluşmaktadır. Araştırmanın örneklemi, küme örnekleme yöntemiyle seçilen 267 okul öncesi öğretmeninden oluşturulmuştur. Veriler, "Sanat ve Estetik Alan Yeterlik Ölçeği” kullanılarak toplanmıştır. Verilerin analizinde aritmetik ortalama, frekans, yüzde, bağımsız gruplar $t$ testi, tek yönlü varyans analizi ve Bonferroni testleri kullanılmıştır. Elde edilen bulgulara göre; okul öncesi öğretmenlerinin sanat ve estetik alanla ilgili öz yeterlik algılarının ölçeğin bilgi sahibi olma ve estetik bakma boyutlarında "yeterli", sanat uygulamalarına yer verme boyutunda ise "biraz yeterli" düzeyinde olduğu tespit edilmiştir. Okul öncesi öğretmenlerinin öz yeterlik algılarının çeşitli değişkenlere göre anlamlı şekilde farklılaştığı görülmüştür. Araştırmada okul öncesi öğretmenlerinin sanat ve estetik değerlerin çocuklara kazandırılmasında öz yeterlik algılarının çok yüksek olmadığı, sanat uygulamaları boyutunda ise nispeten daha düşük olduğu; sanata olan merak ve ilgilerinin öğretmenlerin sanat ve estetik değerleri kazandırma öz yeterlik algılarını olumlu yönde etkilediği sonucuna varılmıştır.

Anahtar Kelimeler: Okul Öncesi öğretmeni, Öğretmen eğitimi, Sanat ve estetik, Sanat eğitimi, Sanat ve estetik yeterlik algısı.

$\&$

Abstract: The purpose of this study is to determine the self-efficacy perceptions of preschool teachers about acquiring art and aesthetic values and to examine whether their self-efficacy perceptions change according to some variables. The research was conducted based on the screening model. The study population consists of 646 preschool teachers working in Trabzon province and town centers. The study sample consisted of 267 preschool teachers selected by cluster sampling method. The data were collected using "Art and Aesthetics Field Competence Scale". Arithmetic mean, frequency, percentages, independent groups t-test, one-way ANOVA, and Bonferroni tests were used in the analysis of data. According to the findings, preschool teachers' self-efficacy perceptions of art and aesthetics were found to be "sufficient" in the dimensions of knowledge and aesthetics, and "somewhat sufficient" in including art practices. It was seen that preschool teachers' self-efficacy perceptions differed significantly 
according to various variables. In the research results, it was observed that the self-efficacy perceptions of preschool teachers to provide art and aesthetics values to students were not very high, and it was relatively low in the art practices dimension; it was concluded that curiosity and interest in art positively affected teachers' self-efficacy perceptions of gaining art and aesthetic values.

Keywords: Preschool teacher, Teacher education, Art and aesthetics, Art education, Art and aesthetic competence perception.

(The Extended Abstract is at the end of the article)

\section{Giriş}

Sanat, çeşitli biçimlerinde (görsel sanatlar, müzik, tiyatro, dans, vb.) çocuğun tüm duyularını içerir; bilişsel becerilerini ve sosyal-duygusal gelişimlerini güçlendirir (Grissmer, Grimm, Aiyer, Murrah ve Steele 2010). Sanat, çocukların neyi yaratabileceklerini görmelerini, denemelerini ve keşfetmelerini sağlar (Schirrmacher, 2006). Sanat çalışmaları, çocuklara kendi düşüncelerini keşfetme ve bu düşünceleri diğer çocuklarla ve yetişkinlerle tartışma firsatı sunar (Novaković, 2015). Sanat, erken çocukluk döneminde yaratıcı, yansıtıcı ve eleştirel düşünceyi geliştirir (James ve Prout, 2015). Bu dönemde yapılan sanat eğitimi çalışmaları, çocukların yaratıcılıklarını ortaya çıkarmada büyük bir potansiyel oluşturur. Ancak bu potansiyeli ortaya çıkarabilmek için sanat eğitimi almış bilgisi iyi olan, estetik bakış açısı kazanmış ve sanatsal etkinlikleri düzenleyebilen öğretmenlere ihtiyaç vardır.

Her çocuk yaratıcı bir potansiyel ile doğar ancak bu potansiyelin ortaya çıkması için yaratıc1lığın beslenmesi ve teşvik edilmesi için özen gösterilmesi gerekir. Aksi halde bu potansiyel ortaya çıkmayabilir (House, Éireann, Foster ve Cliath, 2009). Çocukların yaratıcılıklarının ortaya çıkması ve gelişimi ile sanat etkinliklerine katılımları arasında pozitif yönde bir ilişki vardır (Bancroft, Fawcett ve Hay, 2008; Craft, 2003; Moga, Burger, Hetland ve Winner, 2000; Wilson, 2005). Araştırmalar, erken çocukluk yıllarında çocukların yaratıcı işleyişin zirvesine ulaştığını (Schirrmacher, 2006), bu dönemde sanat etkinliklerinin çocukların estetik ve bilişsel gelişimlerini desteklediğini (Acer, 2015), yaratıcı ve sanatsal becerilerini geliştirdiğini, estetik algılarına ve dünyaya bakış açılarının olumlu yönde gelişmesine yardımcı olduğunu göstermiştir (Alekseevaa, Shkolyara ve Savenkovaa, 2016). Bu nedenle, çocukların estetik bakış açılarının ge- 
lişimi, tutum ve beceriler kazanmaları yönünden okul öncesi dönemdeki sanat eğitimi önemlidir (Gönen, Aydos \& Erdem, 2016). Bu dönemdeki sanat etkinlikleri, çocukların yaratıcılığını ve hayal gücünü kullanarak problem çözme, eleştirel düşünme ve çözüm odaklı olma becerilerinin gelişimine olanak sağlar. Çocukların algılarının yönlendirildiği sanat etkinlikleri meraklarını uyandırır ve duygusal algılarını geliştirir (Novaković, 2015). Sanat etkinlikleri, çocukların kendilerini ifade etmelerine imkân vererek iletişim becerilerinin gelişmesine, yaşadığı kültürü ve diğer kültürleri daha iyi tanımalarını sağlayarak farklılıklara saygı duymasına yardımcı olur ( Milli Eğitim Bakanlığı, 2013). Bunun için sanat ve estetik eğitim için sanat etkinliklerine yer veren nitelikli okul öncesi öğretmenlerine ihtiyaç vardır.

Çocuktaki yaratıcılığın gelişmesinde öğretmenin eğitim düzeyi ve kişiliği çok önemlidir (Argun, 2011). Sınıftaki yaratıcılık, bir öğretmenin çocukları nasıl etkilediğiyle ve öğrenmek için onlara ilham vermesiyle ilgilidir (House, Éireann, Foster ve Cliath (2009). Yaratıcılığı geliştirmek amacıyla çocuklara verilen sanat eğitiminin başarılı bir şekilde uygulanmasında, öğretmenlerin sanat eğitimi ve yaratıcılık konusundaki hazırlık ve inançları belirgin bir rol oynamaktadır (Schirrmacher, 2006). Nitekim birçok çalışma, yaratıcılık eğitimini kolaylaştıran bir sınıf ortamı oluşturmada (Chien ve Hui, 2010; Kampylis, 2010; Wilson, 2001) ve çocukların yaratıcı potansiyellerini ortaya çıkarmada (Cheung ve Mok, 2013; Davies, 2010; Hudson ve Hudson, 2007) öğretmenlerin etkin bir rol oynadığını göstermiştir. Öğretmenlerin yaratıcılık ile ilgili görüşleri, çocukların yaratıcılık kapasitelerinin gelişimi için önemli bir unsurdur (Eckhoff'tan aktaran Runco ve Johnson, 2002). Zira okul öncesi öğretmenlerinin sanatla ilgili görüşleri ile sanatsal etkinliklere yer verme sıklığı arasında bir ilişki bulunmaktadır (Novaković, 2015). Benzer biçimde, Akyıldız (2016) tarafindan yapılan araştırmada, sınıf öğretmenlerinin sanata olan ilgilerinin sanat ve estetik alanındaki yeterlik algılarını olumlu yönde etkilediği tespit edilmiştir. Diğer yandan sanat eğitiminde bilgi, deneyim ve pedagojik açıdan eksik olan bir öğretmenin uygulamalarında bazı problemler ortaya çıkabilmektedir (Ulutaş ve Ersoy 2004). Örneğin bu tür bir öğretmen, yaratıcı düşünmeye değer veren bir sınıf ortamı yerine yaratıcı düşünmenin değer görmediği hatta cesaretinin kırıldığı bir sınıf ortamı oluşturmayı seçebilmektedir (Eckhoff, 2011).

Okul öncesi eğitiminin en önemli amaçlarından biri de çocuğun yaratıcılığını geliştirmektir (Özkan ve Girgin, 2014). Zira bir toplumun gelişmesi ve geleceği o toplumdaki insanların yaratıcılığı ile yakından ilişkilidir (Argun, 2011). Ya- 
ratıcı bireyler yetiştirmek için ise özellikle okul öncesi eğitime büyük görevler düşmektedir. Bu nedenle birçok ülkede ulusal müfredatların sanatsal ve estetik bir boyutu vardır. Ülkemizde de mevcut okul öncesi eğitim programında sanat eğitimine önem verilmekte ve okul öncesi dönemde sanat etkinliklerinin çocukların yaratıcılıklarını geliştirmede önemli olduğu vurgulanmaktadır (MEB, 2013). Programda açı bir biçimde; "Estetik değerleri korur." ve "Sanat eserlerinin değerini fark eder." kazanımlarına yer verilmiştir. Elbette nitelikli bir sanat eğitimi için, yalnızca programların geliştirilmesi, ortamların düzenlenmesi yeterli değildir. Bunun yanında öğretmenlerin sanat eğitimi konusunda gerekli bilgi ve donanıma sahip olmaları gerekir (Özkan ve Girgin, 2014). Diğer yandan etkili bir sanat eğitimi için nitelikli programların geliştirilmesi yanında bu programı uygulayabilecek bilgi ve anlayışa sahip nitelikli öğretmenlere ihtiyaç vardır (Buyurgan ve Buyurgan, 2012). Çocukların yaptığı çalışmaların sanat ve estetik yönüne dikkat çekme, çocuklara beğeni kazandırma ve bu yolla çocukların estetik algılarını geliştirmede öğretmen önemli bir faktördür (Akyıldız, 2016). Özellikle okul öncesi dönemde öğretmenin sanat eğitiminde rolü çok daha önemlidir. Okul öncesi çocuklarının sanat eğitimine katılımları öğretmenlerden aldıkları desteğe bağlıdır (Rose, Jolley ve Burkitt, 2006). Zira "okul öncesi öğretmeninin sanata verdiği önem ve değer, çocuklara sunacağ sanat yaklaşımını ve eğitiminin şekillenmesini doğrudan etkileyecektir" (Aykanat, 2018). Parlakyıldız ve Yıldızbaş (2006) yaptıkları çalışmada, okul öncesi öğretmenlerinin sanatla ilgili eğitimlerinin çocuğun gelişimine katkıda önemli bir rolü olduğunu tespit etmişlerdir. Bu açıdan özellikle okul öncesi öğretmenlerinin sanat ve estetik değeri kazandırma ile ilgili öz yeterlik algıları önemlidir.

Öğretmenlerin öz yeterlik algıları, mesleki nitelik kazanmalarında önemli değişkenlerden biridir. Zira öğrenmeye uygun ortamlar oluşturma başarısı, büyük ölçüde öğretmenlerin yeteneklerine ve öz yeterlik algılarına dayanır. Öğretmen öz-yeterlikleri "öğretmenin, belirli bir durumda belirli bir kalitede belirli öğretim görevlerini yerine getirme yeteneklerine olan bireysel inancı" olarak tanımlanmaktadır (Dellinger, Bobbett, Olivier ve Ellett, 2007). Bandura (1995), öğretmenlerin kişisel öz yeterliklerine ilişkin inançlarının eğitim sürecine ve belirli öğretim faaliyetlerine yönelik genel yönelimlerini etkileyeceğini ileri sürmüştür. Pajares (1992), öğretmenlerin inançlarını, sınıf uygulamalarını etkileyen temel etken olarak görmüştür. Yani öğretmenlerin kendilerini nasıl algıladıkları davranış biçimlerini etkiler. Nitekim araştırma bulguları, öğretmenlerin öğretim etkinlikleri ile ilgili inançlarının sınıf ortamların düzenlemelerinde etkili olduğunu göstermektedir (Bandura, 1993). Öğretmenlerin sanat eğitimin- 
de öz-yeterlikleri güçlü ise, sınıflarında sanat etkinliklerine yer verme olasıllğı daha yüksektir. Öğretmenlerin sanat eğitiminde öz-yeterlikleri zayıfsa, sanat etkinliklerine yer verme olasıllğı daha düşüktür (Garvis ve Pendergast, 2011). Benzer biçimde diğer araştırmacılar da öğretmenlerin kendi mesleki yeterliklerine yönelik algılarının başarı ve verimliliklerini (Ashton ve Webb, 1986), davranış ve tutumlarını (Brownell ve Pajares, 1999), iş doyumlarını (Caprara, Barbaranelli, Steca ve Malone, 2006) etkilediğini vurgulamıştır.

Sanatsal ve estetik eğitimde öğretmenin merkezi bir rolü olduğu düşünülürse, okul öncesi öğretmenlerinin sanat ve estetik değerleri kazandırma ile ilgili yeterlik algılarının ne kadar önemli bir konu olduğu daha iyi anlaşlacaktır. Diğer yandan erken çocukluk eğitiminde sanat eğitimine yönelik öğretmen öz-yeterlik inançları hakkında çok az şey bilinmektedir (Garvis ve Pendergast, 2011). $\mathrm{Bu}$ nedenle bu araştırmada okul öncesi öğretmenlerinin sanat ve estetik değerleri kazandırma ile ilgili öz yeterlik algılarının ortaya çıkarılması araştırmaya değer bir konu olarak görülmüştür. Yapılan literatür taramasında okul öncesi öğretmenlerinin sanat ve estetik değerleri kazandırma ile ilgili yeterliklerini inceleyen bir çalışmaya rastlanmamış olması bu araştırmanın önemini artırmaktadır. Bunun yanında, çalışmada ulaşılacak sonuçların öğretmenlerin performanslarının belirlenmesi ve öğretmenlerin mesleki gelişimlerinin sağlanması amacıyla düzenlenecek eğitimlerin içeriğinin belirlenmesine katkı sağlayacağı söylenebilir.

\section{Araştırmanın Amacı}

Bu araştırmanın amacı, okul öncesi öğretmenlerinin sanat ve estetik değerlerin kazandırılması ile ilgili öz yeterlik algılarını belirlemek ve yeterlik algılarının bazı değişkenlere göre değişip değişmediğini incelemektir. Bu amaç kapsamında aşağıdaki sorulara cevap aranmıştır.

1. Okul öncesi öğretmenlerinin, sanat ve estetik değerleri kazandırma öz yeterlik algıları ne düzeydedir?

2. Okul öncesi öğretmenlerinin, sanat ve estetik değerleri kazandırma öz yeterlik algıları, bir sanat sergisi gezme değişkenine göre farklılık göstermekte midir?

3. Okul öncesi öğretmenlerinin, sanat ve estetik değerleri kazandırma öz yeterlik algıları, bir sanat uğraşısı olup olmama değişkenine göre farklılık göstermekte midir?

4. Okul öncesi öğretmenlerinin, sanat ve estetik değerleri kazandırma öz yeterlik algıları, çocuk çalışmalarını değerlendirmede estetiğe önem verme değişkenine göre farkl1l1k göstermekte midir? 
5. Okul öncesi öğretmenlerinin, sanat ve estetik değerleri kazandırma öz yeterlik algıları, sınıf düzeninde sanat ve estetiğe önem verme değişkenine göre farkl1lık göstermekte midir?

6. Okul öncesi öğretmenlerinin, sanat ve estetik değerleri kazandırma öz yeterlik algıları, sanat etkinliklerine yer verme değişkenine göre farklılık göstermekte midir?

\section{Yöntem}

\section{Araştırmanın Modeli}

$\mathrm{Bu}$ araştırma, nicel araştırma yaklaşımı içerisinde tasarlanmış olup, genel tarama modeline dayalı ilişkisel bir çalışma niteliğindedir. Tarama modeli "geçmişte ya da halen var olan bir durumu olduğu gibi betimlemeyi amaçlayan araştırma yaklaşımıdır. Bu modelde araştırmaya konu edilen durum olduğu gibi tanımlanmaya çalışılır” (Karasar, 2008).

\section{Evren ve Örneklem}

Araştırmanın evreni, 2018-2019 öğretim yılında, bir il ve ile bağlı ilçe merkezlerindeki okullarda görev yapan 646 okul öncesi öğretmeninden oluşmaktadır. Örneklem küme örnekleme yöntemine göre seçilmiştir. "Küme örnekleme yöntemi, çalış1lması düşünülen evrende doğal olarak oluşmuş veya farklı amaçlarla yapay olarak oluşturulmuş, kendi içinde belirli özellikler açısından benzerlik gösteren değişik grupların olması durumunda kullanılır" (Şimşek ve Yıldırım, 2011: 105). Bu yönteme uygun olarak, araştırmanın yapılacağı il ve ilçe merkezindeki ana sınıfları ve bağımsız anaokulları birer küme kabul edilmiş ve bu kümelerden yer alan okullardan rastlantısal olarak belirli sayıda ana sinıfı ve anaokulu belirlenmiştir. Bu okullarda görev yapmakta olan toplam 267 okul öncesi öğretmeni araştırmanın örneklemini oluşturmuştur. Örneklemi oluşturan öğretmenlerin değişkenlere göre dağılımı ise Tablo 1'de verilmiştir. 
Tablo 1: Çalışma Grubunun Çeşitli Özelliklere Göre Dağılımı

\begin{tabular}{|c|c|c|c|}
\hline Değişkenler & Kategoriler & $\mathrm{N}$ & $\%$ \\
\hline \multirow{2}{*}{ 1. Cinsiyet } & 1. Kadın & 253 & 95 \\
\hline & 2. Erkek & 14 & 5 \\
\hline \multirow{4}{*}{$\begin{array}{l}\text { 2. Bir Sanat Sergisi Gezme Durumu (Resim, heykel, } \\
\text { ebru vb.) }\end{array}$} & 1. Hiç gezmedim & 28 & 10 \\
\hline & 2. Bir kez gezdim & 56 & 21 \\
\hline & 3. İki kez gezdim & 48 & 18 \\
\hline & 4. Üç ve üçten çok gezdim & 135 & 51 \\
\hline \multirow{2}{*}{$\begin{array}{l}\text { 3. Bir Sanat Alanında Uğraşısı Olma Durumu (Re- } \\
\text { sim, heykel, ebru vb.) }\end{array}$} & 1. Var & 78 & 29 \\
\hline & 2. Yok & 189 & 71 \\
\hline \multirow{3}{*}{$\begin{array}{l}\text { 4. Çocuk Çalışmalarını Değerlendirmede Sanat ve } \\
\text { Estetiğe Önem Verme }\end{array}$} & 1. Önem veririm. & 169 & 63 \\
\hline & 2. Kısmen önem veririm. & 98 & 37 \\
\hline & 3. Önem vermem. & - & - \\
\hline \multirow{3}{*}{ 5. Sanat etkinliklerini sınıfta uygulama sıklığı. } & 1. Her zaman. & 203 & 76 \\
\hline & 2. Ara sira. & 64 & 24 \\
\hline & 3. Hiç & - & - \\
\hline \multirow{3}{*}{ 6. Sınıfı düzenlemede sanat ve estetiğe önem verme. } & 1. Veriyorum. & 211 & 79 \\
\hline & 2. Kismen veriyorum. & 56 & 21 \\
\hline & 3. Vermiyorum. & - & - \\
\hline Genel Toplam & & 267 & 100 \\
\hline
\end{tabular}

\section{Veri Toplama Aracı}

Araştırma verileri "Sanat ve Estetik Alan Yeterlik Ölçeğì" kullanılarak elde edilmiştir. Başlangıçta 25 maddeden oluşan bir madde havuzu oluşturulmuştur. Başlangıçta bu havuzdan 21 maddelik bir örnek forum hazırlanmış, alınan uzman görüşü sonucunda 6 madde çıkarılmış ve 15 maddeden oluşan bir ölçek geliştirilmiştir. Ölçeğin maddeleri beşli likert tipinde; " $5=$ Her zaman, $4=$ Çoğunlukla, $3=$ Bazen, 2= Ara sıra, 1= Hiçbir zaman" şeklinde cevaplanmaktadır. Ölçeğin 237 öğretmene uygulanması sonucunda elde edilen verilerin yapı geçerliğini test etmek üzere Kaiser-Meyer-Oklin (KMO) ve Bartlett analizleri yapılmıştır. Ölçeği KMO örneklem uyum katsayısı 0.92, Bartlett Küresellik Testi ise 1861.339 olarak hesaplanmıştır (Akyıldız, 2016). Bu hesaplamalardan sonra ölçeğin faktör analizine uygun olduğuna karar verilmiştir. Faktör analiz sonucunda toplam varyansın \% 70.988'ini açıklayan, öz değeri 1'den büyük 3 faktör ortaya çıkmıştır. Ölçeğin faktörlerine ait Cronbach Alpha güvenirlik katsayıları Tablo 2'de verilmiştir (Akyıldız, 2016). 
Tablo 2: Ölçeğin Tamamı ve Alt Ölçeklerin Cronbach Alpha Güvenirlik Katsayıları

\begin{tabular}{lllll}
\hline Alt Ölçekler & $\begin{array}{l}\text { Madde } \\
\text { Sayısı }\end{array}$ & $\begin{array}{l}\text { Faktör } \\
\text { Yükleri }\end{array}$ & $\begin{array}{l}\text { Cronbach } \\
\boldsymbol{\alpha}\end{array}$ & Örnek Maddeler \\
\hline Bilgi Sahibi Olma & 3 & $.56-.82$ & .68 & $\begin{array}{l}\text { Güzel sanatların müzik, görsel sa- } \\
\text { natlar gibi çeşitli alanlarını tanırım. }\end{array}$ \\
\hline Uygulama & 4 & $.63-.84$ & .83 & $\begin{array}{l}\text { Öğrencilerin sanatsal etkinliklere } \\
\text { ilgi duymalarını sağlayacak ortam- } \\
\text { lar düzenlerim. }\end{array}$ \\
\hline Estetik Bakış & 4 & $.75-.83$ & .88 & $\begin{array}{l}\text { Estetik bakış açı̈ını dikkate alarak, } \\
\text { sinıf ortamını örencilerle birlikte } \\
\text { düzenlerim. }\end{array}$ \\
\hline Ölçeğin Tamamı & 11 & $.56-.83$ & .88 & \\
\hline
\end{tabular}

Elde edilen değerler sonucunda ölçeğin tümünün ve alt boyutlarının güvenilir olduğuna karar verilmiştir. Ölçeğin her bir faktöründen alınabilecek en yüksek puan ortalaması 5,00; en düşük puan ortalaması ise 1,00'dır. Bu çalışmada ölçeğin Cronbach Alpha güvenirlik kat sayısı yeniden hesaplanmıştır. Toplanan veriler üzerinden yapılan ölçme işlemi sonucunda; "bilgi sahibi olma" faktörü için .70; "uygulama" faktörü için .82; "estetik bakış” faktörü için .86 ve ölçeğin tamamı için .90 bulunmuştur. Cronbach Alpha değerleri ölçeğin yüksek düzeyde güvenilir olduğunu göstermektedir (Özdamar, 2004).

\section{Verilerin Toplanması ve Analizi}

Araştırma verilerini toplamak amacıyla geliştirilen ölçek formları bir zarfın içinde, öğretmenlere dağıtılmak üzere, okul yöneticilerine teslim edilmiştir. Bir gün sonra ölçekler okul yöneticilerinden geri alınmıştır. Toplanan ölçeklerden eksik bırakılan ölçekler değerlendirme dışında tutulmuş, toplam 267 ölçek değerlendirmeye alınmıştır. Okul öncesi öğretmenlerinin sanat ve estetik değerlerin kazandırılması ile ilgili öz yeterlik algılarının belirlenmesi amacıyla SPSS.20 paket programı kullanılmıştır. Araştırma verilerinin analizinde; betimsel istatistik, öğretmenlerin öz yeterlik algılarının değişkenlere göre değişip değişmediğinin tespit etmek için $\mathrm{t}$ testi ve Tek Yönlü Varyans Analizi (ANOVA) tekniklerinden yararlanılmıştır. Yapılan istatistiksel işlemler sonucunda anlamlı farklılığın ortaya çıktığı durumlarda, farklılıkların hangi gruplar arasında olduğunun belirlenmesi amacıyla, Bonferroni testi uygulanmıştır. Ortalamaların yorumlanmasında Akyıldız (2016) tarafından geliştirilen Tablo 3'de yer alan değerler referans alınmıştır. 
Tablo 3: Ortalamaların Yorumlanmasında Kullanılan Değerler

\begin{tabular}{lll}
\hline Puan Aralı̆̆ & Dereceleme & Yorum \\
\hline $1.00-1.79$ & Hiçbir zaman & Çok yetersiz \\
\hline $1.80-2.59$ & Ara sıra & Yetersiz \\
\hline $2.60-3.39$ & Bazen & Biraz yeterli \\
\hline $3.40-4.19$ & Çoğunlukla & Yeterli \\
\hline $4.20-5.00$ & Her zaman & Çok yeterli \\
\hline
\end{tabular}

\section{Bulgular}

Araştırmada elde elden bulgular alt amaçlara bağlı olarak düzenlenmiştir. Okul öncesi öğretmenlerinin sanat ve estetik değerleri kazandırma yeterlik algılarının "bilgi sahibi olma", "uygulama yapma” ve "estetik bakış açısı" boyutlarına ilişkin yeterlik algılarının aritmetik ortalama ve standart sapma analiz sonuçları Tablo 4'de gösterilmiştir.

Tablo 4: Okul Öncesi Öğretmenlerinin, Sanat ve Estetik Değerleri Kazandırma Öz Yeterlilik Algıları

\begin{tabular}{lllll}
\hline Alt Ölçek & $\mathrm{n}$ & $\overline{\mathrm{X}}$ & $\mathrm{SD}$ & Yorum \\
\hline Bilgi Sahibi Olma & 267 & 3,71 & .74 & Yeterli \\
\hline Uygulama Yapma & 267 & 3,36 & .82 & Biraz yeterli \\
\hline Estetik Bakma & 267 & 3,87 & .75 & Yeterli \\
\hline Ölçeğin Tümü & 267 & 3,64 & .66 & Yeterli \\
\hline
\end{tabular}

Tablo 4'e göre, sanat ve estetik değerleri kazandırma yeterlik algılarının bilgi sahibi olma $(\overline{\mathrm{X}}=3.71)$ ve estetik bakma boyutunda $(\overline{\mathrm{X}}=3.87)$ kendilerini "yeterli" alg1lad1kları; uygulama boyutunda ise kendilerini "biraz yeterli" alg1ladıkları ( $\bar{X}=3.36)$ anlaşılmıştır. Ölçeğin tümü için okul öncesi öğretmenlerinin sanat ve estetik algılarının "yeterli” ( $\overline{\mathrm{X}}=3.64)$ düzeyde olduğu görülmüştür.

Okul öncesi öğretmenlerinin sanat ve estetik değerleri kazandırma yeterliklerinin "bilgi sahibi olma", "uygulama yapma ve "estetik bakma” boyutlarına ilişkin yeterlik algılarının bir sanat sergisi gezme değişkenine ait varyans analiz sonuçları Tablo 5'de verilmiştir. 
Tablo 5: Okul Öncesi Öğretmenlerinin Sanat ve Estetik Değerleri Kazandırma Öz Yeterlik Algılarının "Bir Sanat Sergisi Gezme" Değişkenine Göre Varyans Analiz Sonuçları

\begin{tabular}{|c|c|c|c|c|c|c|c|c|c|c|c|}
\hline $\begin{array}{l}\text { Alt } \\
\text { Öl- } \\
\text { çek }\end{array}$ & $\begin{array}{l}\text { Sanat } \\
\text { Sergisi } \\
\text { Gezme }\end{array}$ & $\mathrm{n}$ & $\overline{\mathrm{X}}$ & ss & $\begin{array}{l}\text { Vary. } \\
\text { Kay. }\end{array}$ & $\begin{array}{l}\text { Kar. } \\
\text { Top. }\end{array}$ & sd & $\begin{array}{l}\text { Kar. } \\
\text { Ort. }\end{array}$ & $\mathrm{F}$ & $\mathrm{p}$ & $\begin{array}{l}\text { Anlamlı } \\
\text { Fark }\end{array}$ \\
\hline \multirow{6}{*}{ 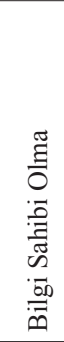 } & Hiç & 28 & 3,50 & .75 & \multirow{2}{*}{$\begin{array}{l}\text { Gruplar } \\
\text { Arası }\end{array}$} & \multirow{2}{*}{8,523} & \multirow{2}{*}{3} & \multirow{2}{*}{2,282} & \multirow{5}{*}{5,441} & \multirow{5}{*}{.001} & \multirow{5}{*}{$\begin{array}{l}2-4 \\
3-4\end{array}$} \\
\hline & Bir kez & 56 & 3,55 & .75 & & & & & & & \\
\hline & İki kez & 48 & 3,53 & .74 & \multirow[b]{2}{*}{$\begin{array}{l}\text { Gruplar } \\
\text { İçi }\end{array}$} & \multirow[b]{2}{*}{137,333} & \multirow[b]{2}{*}{263} & \multirow{3}{*}{, 522} & & & \\
\hline & $\begin{array}{l}\text { Üç ve } \\
\text { üçten } \\
\text { çok }\end{array}$ & 135 & 3,89 & .68 & & & & & & & \\
\hline & Toplam & 267 & 3,71 & .74 & Toplam & 145,856 & 266 & & & & \\
\hline & \multicolumn{2}{|c|}{ Levene: 0,639} & \multicolumn{3}{|c|}{$\mathrm{p}=.591$} & & & & & & \\
\hline \multirow{6}{*}{ 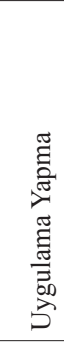 } & Hiç & 28 & 3,32 & .89 & \multirow{2}{*}{$\begin{array}{l}\text { Gruplar } \\
\text { Arası }\end{array}$} & \multirow{2}{*}{2,432} & \multirow{2}{*}{3} & \multirow{2}{*}{, 811} & \multirow{5}{*}{1,204} & \multirow{5}{*}{.309} & \multirow{5}{*}{ - } \\
\hline & Bir kez & 56 & 3,32 & .83 & & & & & & & \\
\hline & İki kez & 48 & 3,19 & .80 & \multirow[b]{2}{*}{$\begin{array}{l}\text { Gruplar } \\
\text { İçi }\end{array}$} & \multirow[b]{2}{*}{177,078} & \multirow[b]{2}{*}{263} & \multirow{3}{*}{, 673} & & & \\
\hline & $\begin{array}{l}\text { Üç ve } \\
\text { üçten } \\
\text { çok }\end{array}$ & 135 & 3,44 & .80 & & & & & & & \\
\hline & Toplam & 267 & 3,36 & .82 & Toplam & 179,510 & 266 & & & & \\
\hline & \multicolumn{2}{|c|}{ Levene: 0,286} & \multicolumn{3}{|c|}{$\mathrm{p}=.836$} & & & & & & \\
\hline \multirow{6}{*}{ 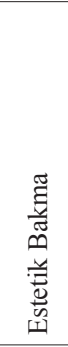 } & Hiç & 28 & 3,85 & .80 & \multirow{2}{*}{$\begin{array}{l}\text { Gruplar } \\
\text { Arasi }\end{array}$} & \multirow{2}{*}{3,064} & \multirow{2}{*}{3} & \multirow{2}{*}{1,021} & \multirow{5}{*}{1,854} & & \\
\hline & Bir kez & 56 & 3,78 & .82 & & & & & & & \\
\hline & İki kez & 48 & 3,70 & .79 & & & & & & & \\
\hline & $\begin{array}{l}\text { Üç ve } \\
\text { üçten } \\
\text { çok }\end{array}$ & 135 & 3,97 & .67 & $\begin{array}{l}\text { Gruplar } \\
\text { İçi }\end{array}$ & 144,857 & 263 &, 551 & & .138 & - \\
\hline & Toplam & 267 & 3,87 & .74 & Toplam & 147,921 & 266 & & & & \\
\hline & Levene: & 599 & & $\mathrm{p}=$. & & & & & & & \\
\hline
\end{tabular}

Tablo 5' e göre, bir sanat sergisi gezmeyen $(\bar{X}=3,50)$, bir kez gezen $(\bar{X}$ $=3,55)$, iki kez gezen ( $\bar{X}=3,53)$ ve üç ve üçten çok sergi gezen $(\bar{X}=3,89)$ okul öncesi öğretmenleri, güzel sanatlar alanında bilgi sahibi olma boyutunda kendilerini "yeterli” görmektedirler. Okul öncesi öğretmenleri, sanat ve estetik değerlerin "bilgi sahibi olma" boyutuna ilişkin görüşlerinin ortalaması $(\bar{X}=3,71)$ bulunmuştur. Buna göre okul öncesi öğretmenlerinin güzel sanatlarla ilgili genel bilgilere sahip olma alanında kendilerini “yeterli” algıladıkları anlaşılmaktadır.

Varyans analiz sonuçlarına göre, okul öncesi öğretmenlerin sanat ve estetik değerlerin "bilgi sahibi olma" boyutuna ilişkin yeterlik algıları bir sanat sergisi gezme değişkenine göre anlamlı düzeyde farklılaşmaktadır $\left(\mathrm{F}_{(3-263)}=5,441\right.$, $\mathrm{p}<.05)$. Bonferroni farklılık testi sonuçlarına göre bu farklılığın üç ve üçten çok sanat sergisi gezen $(\bar{X}=3,89)$ öğretmenler ile bir kez sanat sergisi gezen 
$(\overline{\mathrm{X}}=3,55)$ öğretmenler ve iki kez sanat sergisi gezen $(\overline{\mathrm{X}}=3,53)$ öğretmenler arasında olduğu görülmüştür. Buna göre, üç ve üçten çok sanat sergisi gezen öğretmenlerin bir ve iki kez sanat sergisi gezen öğretmenlere göre sanatla ilgili genel bilgilere sahip olma boyutunda, kendilerini daha yeterli gördükleri anlaŞ1mıştır.

Okul öncesi öğretmenlerinin uygulama yapma boyutunda bir sanat sergisi gezmeyen ( $\overline{\mathrm{X}}=3,32)$, bir kez gezen $(\overline{\mathrm{X}}=3,32)$ ve iki kez gezen $(\overline{\mathrm{X}}=3,19)$ öğretmenler kendilerini "biraz yeterli" görürken, üç ve üçten çok sanat sergisi gezen $(\overline{\mathrm{X}}=3,44)$ öğretmenler kendilerini "yeterli" algılamışlardır. Varyans analizi sonuçlarına göre, okul öncesi öğretmenlerinin sanat ve estetik alanın "uygulama yapma" boyutuna ilişkin yeterlik algıları, bir sanat sergisi gezme değişkenine göre anlamlı farkl111k göstermemiştir $\left(\mathrm{F}_{(3-263)}=1,204, \mathrm{p}>.05\right)$.

Tablo 4'deki bulgulara göre, okul öncesi öğretmenlerinin estetik bakma boyutunda bir sanat sergisini gezmeyen $(\overline{\mathrm{X}}=3,85)$, bir kez gezen $(\overline{\mathrm{X}}=3,78)$, iki kez gezen $(\overline{\mathrm{X}}=3,70)$ ve üç ve üçten çok gezen $(\overline{\mathrm{X}}=3,97)$ öğretmenler kendilerini "yeterli" görmüşlerdir. Varyans analizi sonuçlarına göre, okul öncesi öğretmenlerin sanat ve estetik alanın "estetik bakma" boyutuna ilişkin yeterlik algıları, bir sanat sergisi gezme değişkenine anlamlı farklılık göstermemiştir $\left(\mathrm{F}_{(3-263)}=1,854, \mathrm{p}>.05\right)$.

Okul öncesi öğretmenlerin sanat ve estetik değerleri kazandırma yeterliklerinin "bir sanat alanıyla uğraşma" değişkenine göre bağımsız gruplar t testi sonuçları Tablo 6'da yer almaktadır.

Tablo 6: Okul Öncesi Öğretmenlerinin Sanat ve Estetik Değerleri Kazandırma Yeterlik Algılarının "Bir Sanat Alanıyla Uğraşma” Değişkenine Göre t Testi Sonuçları

\begin{tabular}{|c|c|c|c|c|c|c|c|c|c|}
\hline \multirow{2}{*}{ Alt Ölçek } & \multirow{2}{*}{$\begin{array}{l}\text { Bir Sanatla } \\
\text { Uğraşısı Olma }\end{array}$} & \multirow{2}{*}{$\mathrm{n}$} & \multirow{2}{*}{$\bar{X}$} & \multirow{2}{*}{ Ss } & \multicolumn{2}{|c|}{ Levene Testi } & \multirow{2}{*}{ sd } & \multirow{2}{*}{$\mathrm{t}$} & \multirow{2}{*}{$\mathrm{p}$} \\
\hline & & & & & $\mathrm{F}$ & $\mathrm{p}$ & & & \\
\hline \multirow{2}{*}{$\begin{array}{l}\text { Bilgi Sahibi } \\
\text { Olma }\end{array}$} & Var & 78 & 3,91 & .67 & \multirow{2}{*}{1,352} & \multirow{2}{*}{.246} & \multirow{2}{*}{265} & \multirow{2}{*}{$2.824 *$} & \multirow{2}{*}{.005} \\
\hline & Yok & 189 & 3,63 & .75 & & & & & \\
\hline \multirow{2}{*}{$\begin{array}{l}\text { Uygulama } \\
\text { Yapma }\end{array}$} & Var & 78 & 3,67 & .73 & \multirow{2}{*}{2,122} & \multirow{2}{*}{.146} & \multirow{2}{*}{265} & \multirow{2}{*}{$4.162 *$} & \multirow{2}{*}{.000} \\
\hline & Yok & 189 & 3,23 & .82 & & & & & \\
\hline \multirow{2}{*}{$\begin{array}{l}\text { Estetik } \\
\text { Bakma }\end{array}$} & Var & 78 & 4,08 & .68 & \multirow{2}{*}{$-1,097$} & \multirow{2}{*}{.286} & \multirow{2}{*}{265} & \multirow{2}{*}{$2.958^{*}$} & \multirow{2}{*}{.003} \\
\hline & Yok & 189 & 3,78 & .75 & & & & & \\
\hline
\end{tabular}

Tablo 6'ya göre, güzel sanatlarla ilgili genel bilgiye sahip olmada, bir sanat alanıyla uğraşan $(\overline{\mathrm{X}}=3,91)$ ve bir sanat alanıyla uğraşısı olmayan $(\overline{\mathrm{X}}=3,63)$ okul öncesi öğretmenleri kendilerini “yeterli” görmüşlerdir. Uygulama yapma boyutunda, bir sanat alanıyla uğraşan $(\overline{\mathrm{X}}=3,67)$ öğretmenler kendilerini “yeterli” gö- 
rürken, bir sanat alanıyla uğraşısı olmayan $(\overline{\mathrm{X}}=3,23)$ okul öncesi öğretmenleri kendilerini "biraz yeterli" görmüşlerdir. Estetik bakma boyutunda, bir sanat alanıyla uğraşan $(\overline{\mathrm{X}}=4,08)$ ve bir sanat alanıyla uğraşısı olmayan $(\overline{\mathrm{X}}=3.78)$ okul öncesi öğretmenleri kendilerini “yeterli” gördükleri tespit edilmiştir.

Okul öncesi öğretmenlerinin sanat ve estetik alanla ilgili yeterlik algılarının "sanat uğraşısı olma" değişkenine göre bağımsız gruplar $\mathrm{t}$ testi sonuçları incelendiğinde, öğretmenlerin bilgiye sahip olma $\left[\mathrm{t}_{(265)}=2.824 ; \mathrm{p}=.005\right]$, uygulama yapma $\left[\mathrm{t}_{(265)}=4.162 ; \mathrm{p}=.000\right]$ ve estetik bakma $\left[\mathrm{t}_{(265)}=2.958 ; \mathrm{p}=.003\right]$ alanlarında, bir sanat alanıyla uğraşan okul öncesi öğretmenleriyle herhangi bir sanat alanıyla uğraşmayan okul öncesi öğretmenlerin görüşleri arasında, bir sanat alanıyla uğraşan öğretmenlerin lehine anlamlı farkın olduğu tespit edilmiştir.

Okul öncesi öğretmenlerin sanat ve estetik değerleri kazandırma yeterlik algılarının "Sanat ve estetiğe önem verme" değişkenine göre bağımsız gruplar t testi sonuçları Tablo 7'de yer almaktadır.

Tablo 7: Okul Öncesi Öğretmenlerinin Sanat ve Estetik Değerleri Kazandırma Yeterlik Algılarının "Çocuk Çalışmalarını Değerlendirmede Sanat ve Estetiğe Önem Verme” Değişkenine Göre t Testi Sonuçları

\begin{tabular}{|c|c|c|c|c|c|c|c|c|c|}
\hline \multirow{2}{*}{ Alt Ölçek } & \multirow{2}{*}{$\begin{array}{l}\text { Sanat ve Estetiğe } \\
\text { Önem Verme }\end{array}$} & \multirow{2}{*}{$\mathrm{n}$} & \multirow{2}{*}{$\bar{X}$} & \multirow{2}{*}{ ss } & \multicolumn{2}{|c|}{ Levene Testi } & \multirow{2}{*}{ sd } & \multirow{2}{*}{$\mathrm{t}$} & \multirow{2}{*}{$\mathrm{p}$} \\
\hline & & & & & $\mathrm{F}$ & $\mathrm{p}$ & & & \\
\hline \multirow{2}{*}{$\begin{array}{l}\text { Bilgi Sahibi } \\
\text { Olma }\end{array}$} & Veririm & 169 & 3,92 & .67 & \multirow{2}{*}{,597 } & \multirow{2}{*}{.441} & \multirow{2}{*}{265} & \multirow{2}{*}{$6.445^{*}$} & \multirow{2}{*}{.000} \\
\hline & Kismen veririm & 98 & 3,36 & .72 & & & & & \\
\hline \multirow{2}{*}{$\begin{array}{l}\text { Uygulama } \\
\text { Yapma }\end{array}$} & Veririm & 169 & 3,55 & .77 & \multirow{2}{*}{, 375} & \multirow{2}{*}{.541} & \multirow{2}{*}{265} & \multirow{2}{*}{$5.199 *$} & \multirow{2}{*}{.000} \\
\hline & Kısmen veririm & 98 & 3,03 & .80 & & & & & \\
\hline \multirow{2}{*}{ Estetik Bakma } & Veririm & 169 & 4,02 & .69 & \multirow{2}{*}{2,848} & \multirow{2}{*}{.093} & \multirow{2}{*}{265} & \multirow{2}{*}{$4.422 *$} & \multirow{2}{*}{.000} \\
\hline & Kismen veririm & 98 & 3,61 & .75 & & & & & \\
\hline
\end{tabular}

Tablo 7'ye göre çocukların çalışmalarını değerlendirmede sanat ve estetiğe önem veren okul öncesi öğretmenleri, bilgi sahibi olma boyutunda kendilerini "yeterli" görürken $(\overline{\mathrm{X}}=3.63)$, sanat ve estetiğe kısmen önem veren okul öncesi öğretmenleri kendilerini “biraz yeterli” görmüşlerdir $(\overline{\mathrm{X}}=3.36)$. Benzer şekilde, sanat ve estetiğe önem veren okul öncesi öğretmenleri uygulama yapma boyutunda kendilerini "yeterli" görürken $(\overline{\mathrm{X}}=3.55)$, sanat ve estetiğe kısmen önem veren okul öncesi öğretmenleri kendilerini "biraz yeterli" görmüşlerdir $(\bar{X}=3.36)$. Sanat ve estetiğe önem veren $(\bar{X}=4.02)$, sanat ve estetiğe kısmen önem veren okul öncesi öğretmenleri ( $\overline{\mathrm{X}}=3.61)$ estetik bakma boyutunda kendilerini “yeterli" algılamışlardır. 
Okul öncesi öğretmenlerinin sanat ve estetik alanla ilgili yeterlik algılarının "çocuk çalışmalarını değerlendirmede sanat ve estetiğe önem verme" değişkenine göre bağımsız gruplar $\mathrm{t}$ testi sonuçlarına göre; öğretmenlerin bilgiye sahip olma $\left[\mathrm{t}_{(265)}=6.445 ; \mathrm{p}=.000\right]$, uygulama yapma $\left[\mathrm{t}_{(265)}=5.199 ; \mathrm{p}=.000\right]$, sanat ve estetik bakma $\left[\mathrm{t}_{(265)}=4.422 ; \mathrm{p}=.000\right]$ alanlarında, sanat ve estetiğe önem veren okul öncesi öğretmenler ile sanat ve estetiğe önem vermeyen okul öncesi öğretmenlerin görüşleri arasında, sanat ve estetiğe önem veren öğretmenlerin lehine anlamlı farkın olduğu gözlenmiştir.

Okul öncesi öğretmenlerin sanat ve estetik değerleri kazandırma yeterlik algılarının "slnıf düzeninde sanat ve estetiğe önem verme" değişkenine göre bağımsız gruplar $\mathrm{t}$ testi sonuçları Tablo 8'de yer almaktadır.

Tablo 8: Okul Öncesi Öğretmenlerinin Sanat ve Estetik Değerleri Kazandırma Yeterlik Algılarının "Sınıf Düzeninde Sanat ve Estetiğe Önem Verme” Değişkenine Göre t Testi Sonuçları

\begin{tabular}{|c|c|c|c|c|c|c|c|c|c|}
\hline \multirow[b]{2}{*}{ Alt Ölçek } & \multirow{2}{*}{$\begin{array}{l}\text { Sinıf Düzeninde } \\
\text { Sanat ve Estetiğe } \\
\text { Önem Verme }\end{array}$} & \multirow[b]{2}{*}{$\mathrm{n}$} & \multirow[b]{2}{*}{$\overline{\mathrm{X}}$} & \multirow[b]{2}{*}{ ss } & \multicolumn{2}{|c|}{ Levene Testi } & \multirow[b]{2}{*}{$\mathrm{sd}$} & \multirow[b]{2}{*}{$\mathrm{t}$} & \multirow[b]{2}{*}{$\mathrm{p}$} \\
\hline & & & & & $\mathrm{F}$ & $\mathrm{p}$ & & & \\
\hline \multirow{2}{*}{$\begin{array}{l}\text { Bilgi Sahibi } \\
\text { Olma }\end{array}$} & Veriyorum & 211 & 3,80 & .72 & \multirow[b]{2}{*}{0,005} & \multirow[b]{2}{*}{.945} & \multirow[b]{2}{*}{265} & \multirow{2}{*}{$3.640^{*}$} & \multirow[b]{2}{*}{.000} \\
\hline & Kismen Veriyorum & 56 & 3,40 & .73 & & & & & \\
\hline \multirow{2}{*}{$\begin{array}{l}\text { Uygulama } \\
\text { Yapma }\end{array}$} & Veriyorum & 211 & 3,48 & .78 & \multirow{2}{*}{0,276} & \multirow{2}{*}{.600} & \multirow{2}{*}{265} & \multirow{2}{*}{$4.725^{*}$} & \multirow{2}{*}{.000} \\
\hline & Kismen Veriyorum & 56 & 2,91 & .81 & & & & & \\
\hline \multirow{2}{*}{$\begin{array}{l}\text { Estetik } \\
\text { Bakma }\end{array}$} & Veriyorum & 211 & 3,98 & .69 & \multirow{2}{*}{2,416} & \multirow{2}{*}{.121} & \multirow{2}{*}{265} & \multirow{2}{*}{$4.981 *$} & \multirow{2}{*}{.000} \\
\hline & Kismen Veriyorum & 56 & 3,45 & .77 & & & & & \\
\hline
\end{tabular}

Tablo 8'e göre, sinıf düzeninde sanat ve estetiğe önem veren $(\bar{X}=3.80)$ ve kısmen önem veren ( $\overline{\mathrm{X}}=3.40)$ okul öncesi öğretmenleri kendilerini bilgi sahibi olma boyutunda "yeterli" görmüşlerdir. Sınıf düzeninde sanat ve estetiğe önem veren $(\overline{\mathrm{X}}=3.48)$ okul öncesi öğretmenleri uygulama yapma boyutunda kendilerini "yeterli" görürken, sınıf düzeninde sanat ve estetiğe kısmen önem veren $(\overline{\mathrm{X}}=2.91)$ okul öncesi öğretmenleri kendilerini "biraz yeterli" görmüşlerdir. Sınıf düzeninde sanat ve estetiğe önem veren $(\overline{\mathrm{X}}=3.98)$ ve kısmen önem veren $(\overline{\mathrm{X}}=3.45)$ okul öncesi öğretmenleri estetik bakma boyutunda kendilerini "yeterli" görmüşlerdir.

Okul öncesi öğretmenlerinin sanat ve estetik alanla ilgili yeterlik algılarının "sınıf düzeninde sanat ve estetiğe önem verme" değişkenine göre bağımsız gruplar $\mathrm{t}$ testi bulgularına göre; öğretmenlerin bilgiye sahip olma $\left[\mathrm{t}_{(265)}=3.640\right.$; $\mathrm{p}=.000]$, uygulama yapma $\left[\mathrm{t}_{(265)}=4.725 ; \mathrm{p}=.000\right]$ ve estetik bakma $\left[\mathrm{t}_{(265)}=4.981\right.$; $\mathrm{p}=.000]$ boyutlarında, sınıf düzeninde sanat ve estetiğe önem veren okul öncesi 
öğretmenler ile sınıf düzeninde sanat ve estetiğe kısmen önem veren okul öncesi öğretmenlerinin görüşleri arasında, sınıf düzeninde sanat ve estetiğe önem veren öğretmenlerin lehine, anlamlı fark ortaya çıkmıştır.

Okul öncesi öğretmenlerin sanat ve estetik değerleri kazandırma yeterlik algılarının "sanat etkinliklerine yer verme" değişkenine göre bağımsız gruplar t testi sonuçları Tablo 9'da yer almaktadır.

Tablo 9: Okul Öncesi Öğretmenlerinin Sanat ve Estetik Değerleri Kazandırma Yeterlik Algılarının "Sanat Etkinliklerine Yer Verme" Değişkenine Göre t Testi Sonuçları

\begin{tabular}{|c|c|c|c|c|c|c|c|c|c|}
\hline \multirow{2}{*}{ Alt Ölçek } & \multirow{2}{*}{$\begin{array}{l}\text { Sanat Etkinliklerine } \\
\text { Yer Verme }\end{array}$} & \multirow{2}{*}{$\mathrm{n}$} & \multirow{2}{*}{$\bar{X}$} & \multirow{2}{*}{ ss } & \multicolumn{2}{|c|}{ Levene Testi } & \multirow{2}{*}{ sd } & \multirow{2}{*}{$\mathrm{t}$} & \multirow{2}{*}{$\mathrm{p}$} \\
\hline & & & & & $\mathrm{F}$ & $\mathrm{p}$ & & & \\
\hline \multirow{2}{*}{$\begin{array}{l}\text { Bilgi Sahibi } \\
\text { Olma }\end{array}$} & Her zaman & 203 & 3,80 & .70 & \multirow[b]{2}{*}{1,451} & \multirow[b]{2}{*}{.229} & \multirow[b]{2}{*}{265} & \multirow[b]{2}{*}{$3.687^{*}$} & \multirow[b]{2}{*}{.000} \\
\hline & Ara sira & 64 & 3,42 & .77 & & & & & \\
\hline \multirow{2}{*}{$\begin{array}{l}\text { Uygulama } \\
\text { Yapma }\end{array}$} & Her zaman & 203 & 3,45 & .78 & \multirow{2}{*}{1,246} & \multirow{2}{*}{.265} & \multirow{2}{*}{265} & \multirow{2}{*}{$3.427^{*}$} & \multirow{2}{*}{.001} \\
\hline & Ara sira & 64 & 3,06 & .86 & & & & & \\
\hline \multirow{2}{*}{$\begin{array}{l}\text { Estetik } \\
\text { Bakma }\end{array}$} & Her zaman & 203 & 3,95 & .72 & \multirow{2}{*}{$-1,557$} & \multirow{2}{*}{.213} & \multirow{2}{*}{265} & \multirow{2}{*}{$3.159 *$} & \multirow{2}{*}{.002} \\
\hline & Ara sira & 64 & 3,62 & .76 & & & & & \\
\hline
\end{tabular}

Tablo 9'a göre, sanat etkinliklerine her zaman yer veren $(\bar{X}=3.80)$ ve sanat etkinliklerine ara sıra yer veren $(\overline{\mathrm{X}}=3.42)$ okul öncesi öğretmenleri kendilerini bilgi sahibi olma boyutunda "yeterli" görmüşlerdir. Sanat etkinliklerine her zaman yer veren $(\overline{\mathrm{X}}=3.45)$ okul öncesi öğretmenleri kendilerini uygulama boyutunda "yeterli" görürken, sanat etkinliklerine ara sira yer veren $(\overline{\mathrm{X}}$ =3.06) okul öncesi öğretmenleri kendilerini "biraz yeterli" görmüşlerdir. Sanat etkinliklerine her zaman yer veren $(\bar{X}=3.95)$ ve sanat etkinliklerini ara sira yer veren ( $\overline{\mathrm{X}}=3.62$ ) okul öncesi öğretmenleri estetik bakma boyutunda kendilerini "yeterli" görmüşlerdir.

Okul öncesi öğretmenlerinin sanat ve estetik alanla ilgili yeterlik algılarının "sanat etkinliklerine yer verme" değişkenine göre bağımsız gruplar $t$ testi hesaplanmıştır. Buna göre; öğretmenlerin bilgiye sahip olma $\left[\mathrm{t}_{(265)}=3.687 ; \mathrm{p}=.000\right]$, uygulama yapma $\left[\mathrm{t}_{(265)}=3.427 ; \mathrm{p}=.001\right]$ ve estetik bakma $\left[\mathrm{t}_{(265)}=3.159 ; \mathrm{p}=.002\right]$ alanlarında, sanat etkinliklerine her zaman yer veren okul öncesi öğretmenler ile sanat etkinliklerine ara sıra yer veren okul öncesi öğretmenlerinin görüşleri arasında, sanat etkinliklerine her zaman yer veren öğretmenlerin lehine anlamlı fark ortaya çıkmıştır. 


\section{Tartişma}

$\mathrm{Bu}$ araştırmada, okul öncesi öğretmenlerinin sanat ve estetik değerleri kazandırma öz yeterlik algılarının ne düzeyde olduğu, sanat ve estetik yeterlik algılarının sanat sergisi gezme, bir sanat uğraşısı olma, çocuk çalışmalarını değerlendirmede sanat ve estetiğe önem verme, sanat etkinliklerine yer verme durumu ve sın1fını düzenlemede sanat ve estetiğe önem verme değişkenlerine göre değişip değişmediği araştırılmış, elde edilen bulgular ilgili literatür ışığında tartışılmıştır.

Araştırma bulgularına göre, okul öncesi öğretmenlerinin sanat ve estetik değerleri kazandırma öz yeterlik algılarının ölçeğin tamamında, bilgi sahibi olma ve estetik bakma alt boyutlarında kendilerini "yeterli" görürken, uygulama yapma boyutunda kendilerini "biraz yeterli" gördükleri tespit edilmiştir. Okul öncesi öğretmen adaylarının genel olarak sanat ve estetik değerleri kazandırma öz yeterlik algılarının çok yüksek olmadığı sanat uygulamalarında ise öz yeterlik algılarının nispeten düşük düzeyde kaldığı görülmektedir. Okul öncesi öğretmenlerinin bilgi sahibi olma, estetik bakma boyutlarında öz yeterlik alg1larının çok yüksek olmamasının, uygulama yapma boyutunda ise nispeten düşük olmasının nedeni sanat alanında yeterli bir eğitim alamamış olmalarından ve deneyim eksikliğinden kaynaklandığ 1 söylenebilir. Nitekim Benić, Herzog ve Sušić (2017), ilköğretim ve erken çocukluk eğitimi öğretmenlerinin sanat ve yaratıcılığın eğitimdeki önemi ile ilgili tutumlarının ve mesleki yeterlik algılarının yanında, başlangıçta aldıkları eğitimin kalitesine bağlı olabileceğini ileri sürmüştür. Garvis ve Pendergast (2011), sanat içerik bilgisinin öğretmen öz yeterliğinin önemli bir kaynağı olduğunu ifade etmiştir. Benzer diğer çalışmalar, öğretmen adaylarının sanat eğitiminde yeterli deneyime sahip olmadığını göstermektedir (Bilir-Seyhan ve Sakire, 2018; Gönen, Aydos ve Erdem, 2016; Welch, 1995). Bunun yanında okul öncesi öğretmenleri de lisans eğitiminde aldıkları sanat eğitimi derslerinin yetersiz olduğu düşüncesinde oldukları (Özkan ve Girgin, 2014) anlaşılmıştır.

Okul öncesi öğretmenlerinin sanat ve estetik değerlerin kazandırılması ile ilgili öz yeterlik algıları, "bir sanat sergisi gezme", "bir sanat alanıyla uğraşma", "çocuk çalışmalarını değerlendirmede sanat ve estetiği önem verme", "s1nıf düzeninde sanat ve estetiğe önem verme", "sanat etkinliklerine yer verme" değişkenlerine göre değerlendirilmiştir. Elde edilen bulgulara göre, daha çok sanat sergisi gezen okul öncesi öğretmenlerinin sanat ve estetik değerleri kazandırma alanının bilgi sahibi olma boyutunda öz yeterlik algılarının yüksek ol- 
duğu görülmüştür. Diğer yandan bir sanat alanıyla uğraşan, çocuk çalışmalarını değerlendirmede ve sınıf düzeninde sanat ve estetiğe önem veren, sinıfta sanat etkinliklerine yer veren okul öncesi öğretmenlerinin sanat ve estetik değerleri kazandırmada kendilerini daha yeterli gördükleri anlaşılmıştır.

Öğretmenlerin sanat sergileri gezmeleri, sanatla uğraşmaları çocuk çalışmalarını değerlendirme ve sınıf düzeninde sanat ve estetiğe önem vermeleri, sanat etkinliklerine yer vermeleri öğretmenlerin sanata olan merak ve ilgilerinin göstergeleri olarak ele alınabilir. Zira bireylerin sahip oldukları özel beceriler ve ilgi alanları onların becerilerini deneme ve kullanma isteklerini harekete geçirebilir (Gültekin, 2011). Nitekim sanatın insana haz verdiği ve estetik duygu kazandırdığı (Mercin ve Alakuş, 2007), estetik düşünce, yaratıcı gücü ve potansiyeli destekleyerek pratik düşünce becerisi geliştirdiği (Aykanat, 2018), bireylerin zihnen ve ruhen dengeli olmalarına katkı sağladığı (Özkeçeci, 2009) bilinmektedir. Diğer yandan, okul öncesi öğretmenlerinin sanatla ilgili görüşleri ile sanatsal etkinliklere yer verme sıklığı arasında bir ilişki bulunmaktadır (Novaković, 2015). Nitekim araştırmalar, sanat bilgi ve becerilerinde öz-yeterliği düşük olan öğretmenlerin sınıflarında sanat öğretimini sınırladığını (Garvis, 2008; Garvis ve Pendergast, 2010), çalışmalarında sanat eğitimi alan ergenlerin yaratıcılık boyutunda aldıkları puan ortalamalarının sanat eğitimi almayanlara göre anlamlı bir şekilde yüksek olduğunu (Aral, 1999), öğretmenlerin sanat sergisi gezme sıklıkları arttıkça sanat ve estetik alanla ilgili bilgi sahibi olma yeterliklerinin de arttığını (Akyıldız, 2016) göstermiştir.

Öğretmen öz yeterlik inançları, sınıfta öğretmen davranışı için önemli bir motivasyon kaynağıdır ve öğretmenlerin kendi öz yeterlikleri ile ilgili öznel algıları sanattaki gerçek performanslarını etkileyebilmektedir (Garvis ve Pendergast, 2011). Araştırmalar, öğretmenlerin sanat alanıyla ilgili bilgi ve becerilerinin yanı sıra sanata olan ilgileri ile öz yeterlik algıları arasında bir ilişki olduğuna işaret etmektedir. Araştırma bulgularına paralel olarak bu çalışmada okul öncesi öğretmenlerinin sanata olan merak ve ilgilerinin öğretmenlerin sanat ve estetik değerleri kazandırma öz yeterlik algılarının yüksek olmasına olumlu yönde etki ettiği sonucuna varılmıştır.

Okul öncesi dönemde çocukların yaratıcılıklarının gelişimi için sanat ve estetik eğitiminin önemine vurgu yapılmaktadır. Ancak öğretmenler sanat eğitimi için güçlü bir öz yeterliliğe sahipse, sınıfta sanat eğitimine yer vermeleri olasıdır. Eğer öğretmenler sanat eğitimi için öğretmen öz yeterliliğine sahip değilse, sınıfta sanat uygulamalarına yer vermeleri daha az olasıdır (Garvis ve 
Pendergast, 2011). Bu bağlamda araştırma bulgularından hareketle okul öncesi öğretmenlerinin sanat ve estetik değerleri kazandırma öz yeterlik algılarının geliştirilmesine yönelik aşağıdaki öneriler geliştirilmiştir.

- Okul öncesi eğitim programlarında yer alan sanat ve estetik alanla ilgili ders içerikleri zenginleştirilebilir ve sanat etkinliklerini düzenlemede öğretmen adaylarına beceri kazandırıcı nitelikte olmaları sağlanabilir.

- Alandaki okul öncesi öğretmenleri sürekli mesleki gelişim kapsamında, okul yöneticileri tarafından, sanat sergileri gezme, sanat alanıyla uğraşma, sanat etkinliklerine yer verme, sanat kurslarına gitme vb. alanlarda teşvik edilebilir.

- Alandaki okul öncesi öğretmenlerinin sanat uygulamaları ile ilgili yaptıkları iyi uygulamalar diğer öğretmenlerin paylaşımına sunulabilir.

- Alandaki okul öncesi öğretmenlerine sanat etkinlikleri düzenleme becerilerini geliştirmek amacına yönelik hizmet içi eğitim faaliyetleri düzenlenebilir.

- Okul öncesi eğitiminde, öğretmenlerin sanat ve estetik eğitimleri ile ilgili daha derinlemesine çalışmalar yapılarak, öğretmenlerin sanat ve estetik eğitim ile ilgili yeterlikleri ve yaşadıkları problemler belirlenebilir.

- Araştırmacılar diğer alanlardaki öğretmenlerin sanat ve estetik değerleri kazandırma öz yeterlik algılarını inceleyebilirler.

\section{Kaynakça}

Acer, D. (2015). The arts in Turkish preschool education. Arts Education Policy Review, 116(1), 43-50.

Akyıldız, S. (2016). Sınıf öğretmenlerinin sanat ve estetik alanla ilgili yeterlik algılarının bazı değişkenler açısından incelenmesi, Dicle Üniversitesi, Eğitim Fakültesi Dergisi, 27, 71-82.

Alekseevaa, L., Shkolyara L., \& Savenkovaa L. (2016). "Garden of childhood” As an innovative approach to training and education of children at preschool institutions. International Journal of Environmental \& Science Education, 11(10), 3345-3351.

Aral, N. (1999). Sanat eğitimi-yaratıcılık etkileşimi. Hacettepe Üniversitesi Eğitim Fakültesi Dergisi, 15(15), 11-17.

Argun, Y. (2011). Okul öncesi dönemde yaratıcllı ve eğitimi (2. Baskı). Ankara: Anı Yayıncilık.

Ashton, P. T. \& Webb, R. B. (1986). Making a difference: teachers'sense of efficacy and Longman. Publishing Group. 
Aykanat, E. (2018). Okul öncesi öğretmenlerinin sanat eğitimine yönelik tutumlarını belirlemek üzere ölçek geliştirme çalışması (Yüksek lisans tezi). Başkent Üniversitesi Eğitim Bilimleri Enstitüsü, Ankara.

Bancroft, S., Fawcett, M., \& Hay, P. (2008). Researching children researching the world: $5 \times 5 \times 5=$ creativity. Stoke-on-Trent: Trentham Books.

Bandura, A. (1993). Perceived self-efficacy in cognitive development and functioning. Educational psychologist, 28(2), 117-148.

Bandura, A. (1995). Self-efficacy in changing societies. Cambridge University Press.

Benić, M. Ž., Herzog, J., \& Sušić, B. B. (2017). Early childhood education-students' self-assessment of their teaching competences in the arts. New Trends and Issues Proceedings on Humanities and Social Sciences, 4(10), 66-78.

Bilir-Seyhan, G., \& Sakire, O. K. (2018). Early childhood pre-service teachers' views about visual arts education and aesthetics. Eurasian Journal of Educational Research, 18(73), 131-148.

Brownell, M.T. \& Pajares, F. (1999). Teacher efficacy and perceived success in mainstream in gstudents with learning and behavior problems. Teacher Educationand Special Education, 22(3), 154-164.

Buyurgan, S., \& Buyurgan, U. (2012). Sanat eğitimi ve öğretimi. Ankara: Pegem Akademi.

Caprara, G. V., Barbaranelli, C., Steca, P. \& Malone, P. S. (2006). Teachers' self-efficacybeliefs as determinants of jobsatisfactionandstudents' academicachievement: A study at theschoollevel. Journal of School Psychology, 44(6), 473-490.

Cheung, R. H. P., \& Mok, M. M. C. (2013). A study of early childhood teachers' conceptions of creativity in Hong Kong. Educational Psychology, 33, $119-133$.

Chien, C. Y., \& Hui, A. N. (2010). Creativity in early childhood education: Teachers' perceptions in three Chinese societies. Thinking Skills and Creativity, 5(2), 49-60.

Craft, A. (2003). Creative thinking in the early years of education. Early Years, 23, $143-154$.

Davies, D. (2010). Enhancing the role of the arts in primary pre-service teacher education. Teaching and Teacher Education, 26, 630-638.

Dellinger, A. B., Bobbett, J. J., Olivier, D.F., \& Ellett, C.D. (2007). Measuring teachers' self efficacy beliefs: Development and the use of the TEBS-Self. Teaching and Teacher Education (2007, Ekim 4). Erişim adresi: http://www. sciencedirect.com. 
Eckhoff, A. (2011) Creativity in the Early Childhood Classroom: Perspectives of Preservice Teachers, Journal of Early Childhood Teacher Education, 32(3), 240-255. doi:10.1080/10901027.2011.594486

Garvis, S. (2008). Teacher self-efficacy for the arts education: Defining the construct. Australian Journal of Middle Schooling, 8(1), 25-31.

Garvis, S., \& Pendergast, D. (2010). Middle years teachers' past experiences of the arts: Implications for teacher education. Australian Journal of Music Education, 2, 28-40.

Garvis, S., \& Pendergast, D. (2011). An investigation of early childhood teacher self-efficacy beliefs in the teaching of arts education. International Journal of Education \& The Arts, 12(9), 1-15.

Gönen, M., Aydos, E., H. \& Erdem, A., Ü. (2016). Experiences of candidate preschool teachers on art education and implementations, International Journal of Innovative Research in Education, 3(1), 42-49. doi: 10.18844/ijire.v1i1.118.

Grissmer, D., Grimm, K. J., Aiyer, S. M., Murrah, W. M., \& Steele, J. S. (2010). Fine motor skills and early comprehension of the world: two new school readiness indicators. Developmental Psychology, 46(5), 1008.

Gültekin, T. (2011). Sanat eğitiminde estetik değerlerin gelişimi sürecinde çocuk ve iletişim. Akademik Bakış Dergisi, 24, 1-14.

House, V. F., Éireann, C. M., Foster, Á. V., \& Cliath, B. Á. (2009). Creativity and the arts in the primary school. In Discussion Document and Proceedings of the Consultative Conference on Education.

Hudson, P. \& Hudson, S. (2007). Examining preservice teachers' preparedness for teaching art. International Journal of Education \& the Arts, 8(5), 1-24

James, A., \& Prout, A. (Eds.). (2015). Constructing and reconstructing childhood: Contemporary issues in the sociological study of childhood. Routledge.

Kampylis, P. (2010). Fostering creative thinking: The role of primary teachers (Unpublished doctoral dissertation). The University of Jyvaskyla, Finland.

Karasar, N. (2008). Bilimsel araştırma yöntemi: kavramlar-ilkeler-teknikler. Ankara: Nobel Yayın Dağıtım.

MEB. (2013). Okul Öncesi Eğitim Programı (2019, Haziran 16). Erişim adresi: https://tegm.meb.gov.tr/dosya/okuloncesi/ooproram.pdf

Mercin, L. \& Alakuş, A. O. (2007). Birey ve toplum için sanat eğitiminin gerekliliği. Ziya Gökalp Ĕgitim Fakültesi Dergisi, 9, 14-20.

Moga, E., Burger, K., Hetland, L., \& Winner, E. (2000). Does studying the arts engender creative thinking? Evidence for near but not far transfer. Journal of Aesthetic Education, 34, 91-104. 
Novaković, S. (2015). Preschool teacher's role in the art activities of early and preschool age children. Croatian Journal of Education: Hrvatski časopis za odgoj i obrazovanje, 17(1), 153-163.

Özdamar, K. (2004). Paket programlar ile istatistiksel veri analizi II. Eskişehir: Kaan Kitabevi

Özkan, B., \& Girgin, F. (2014). Okul öncesi öğretmenlerinin görsel sanat etkinliği uygulamalarını değerlendirmesi. Ejovoc (Electronic Journal of Vocational Colleges), 4(4), 79-85.

Özkeçeci, İ. (2009) Eğitime sanatın katkıları ve yansımaları. In: 1st International Symposium on Sustainable Development, June 9-10, 2009, Sarajevo, Bosnia and Herzegovina.

Pajares, M. F. (1992). Teachers' beliefs and educational research: Cleaning up a messy construct. Review of Educational Research, 62, 307-332.

Parlakyıldız, B. \& Yıldızbaş, F. (2006). Okulöncesi sanat etkinliklerinde artık materyallerin kullanılmasına ilişkin öğretmen görüşleri. Abant İzzet Baysal Üniversitesi Eğitim Fakültesi Dergisi, 6(1), 39-49.

Rose, S. E. Jolley, R. P. \& Burkitt, E. (2006). A review of children's, teachers' and parents' influences on children's drawing experience. International Journal of Art and Design Education, 25(3), 341-349.

Schirrmacher, R. (2006). Art and creative development for young children. (7th Ed.). USA: Thomson Delmar Learning.

Şimşek, H., \& Yıldırım, H. A. (2011). Sosyal bilimlerde nitel araştırma yöntemleri. Ankara: Seçkin Yayıncılık.

Ulutaş, İ., \& Ersoy, Ö. (2004). Okul öncesi dönemde sanat eğitimi. Kastamonu Ĕgitim Dergisi, 12(1), 1-12.

Welch, A. (1995). The self-efficacy of primary teachers in art education. Issues in Educational Research, 5(1), 71-84.

Wilson, A. (Ed.). (2005). Creativity in primary education. Learning Matters.

Wilson, D. (2001). Guidelines for coaching student composers. Music Educators Journal, 88(1), 28-33. 
Extended Abstract

\section{Examining Preschool Teachers' Self-Efficacy Perceptions in Helping Students Acquire Artistic and Aesthetic Values}

Salih AKYILDIZ, Corresponding Author, Associate Professor.

Trabzon University, Fatih Faculty of Education, Turkey.

sakyildiz61@gmail.com

http://orcid.org/0000-0002-8569-7411

Article Type: Research Article

https://doi.org/10.34234/ded.629922

Received Date: 09.10 .2019

Accepted Date: 12.01 .2020

Published Date: 25.06.2020

\section{Introduction}

Art involves all the senses of children in various forms (visual arts, music, theatre, dance, etc.) and strengthens their cognitive skills and social-emotional development (Grissmer et al., 2010). Art allows children to see, experiment, and discover what they can create (Schirrmacher, 2006). Artworks give children the opportunity to explore their own thoughts and discuss them with other children and adults (Novaković, 2015). Art develops creative, reflective and critical thinking in early childhood (James \& Prout, 2015).

Every child is born with a creative potential, however, their creativity need to be nurtured and promoted to reveal this potential. Otherwise, this potential might not be discovered (House, Éireann, Foster \& Cliath, 2009). There is a positive relationship between revealing and developing children's creativity and their participation in art activities (Bancroft, Fawcett \& Hay, 2008; Craft, 2003; Moga, Burger, Hetland \& Winner, 2000; Wilson, 2005). Research shows that children reached the peak of creative functioning in their early childhood years (Schirrmacher, 2006) where art activities do support children's aesthetics and 
cognitive development (Acer, 2015), develop their creative and artistic skills, help them develop their aesthetic perceptions and encourage them to view of the world in a positive way (Alekseevaa, Shkolyara \& Savenkovaa, 2016).

During preschool period, teacher is an important factor to lead children into creativity. The educational level and personality of the teacher are significant in the development of children's creativity (Argun, 2011). Creativity in classroom is about how teachers influence their students and inspire them to learn (House, Éireann. Foster \& Cliath, 2009). Teachers' preparedness and beliefs about art education and creativity play an important role in the successful implementation of art education for children to develop their creativity (Schirrmacher, 2006). As a matter of fact, many studies showed that teachers play an important role of creating a classroom environment that facilitates creativity education (Chien \& Hui, 2010; Kampylis, 2010; Wilson, 2001) and revealing children's creative potential (Cheung \& Mok, 2013; Davies, 2010; Hudson \& Hudson, 2007). Teachers views related to creativity are essential for development of children's creative capacity (Runco \& Johnson, 2002 cited in Eckhoff, 2011), thus, there is a relationship between preschool teachers' views on art and the frequency of artistic activities (Novaković, 2015). Similarly, in the study conducted by Akyildiz (2016), found that the interest of classroom teachers in art, positively influenced their perceptions of competence in the field of art and aesthetics.

Teacher self-efficacy is defined as "teacher's individual belief in the ability to perform specific teaching tasks of a particular quality in a particular situation" (Dellinger et al., 2007, p.2). Bandura (1995) suggested that teachers' beliefs about their self-efficacy would affect their general inclination towards the educational process and specific training activities. Pajares (1992) identified teachers' beliefs as the main factor of affecting class practices. In addition, research findings showed that teachers' beliefs about teaching activities are effective in their designing of the classroom environments (Bandura, 1993). If teachers' self-efficacy is strong in art education, they are more likely to include art activities in their classrooms. If teachers' self-efficacy is weak in art education, they are less likely to include art activities (Garvis \& Pendergast, 2011).

Considering the significant role of the teacher in art and aesthetic education, the importance of preschool teachers' perceptions of their competence in providing art and aesthetic values, are better understood. Thus, in this research, it is seen that preschool teachers' self-efficacy perceptions about acquiring art and aesthetics values are worth to investigate. It can be said that the results of 
the study will contribute to the development of teachers' training programs contents in terms of determining teachers' performances and to ensure teachers' professional development.

\section{Purpose of the Research}

The purpose of this study is to determine the self-efficacy perceptions of preschool teachers about transferring artistic and aesthetic values and to examine whether their self-efficacy perceptions change according to some variables. The following are the research questions:

1. What is the self-efficacy perception level of preschool teachers for providing artistic and aesthetic values?

2. Do preschool teachers' self-efficacy perceptions of providing artistic and aesthetic values show differences according to the variables such as; visiting an art exhibition, having an artistic engagement, giving attention to aesthetics in evaluating student works, giving opportunities for art activities, or giving attention to art and aesthetics in classroom design?

\section{Method}

This research is designed as a quantitative research approach and it is a relational study based on a general screening model. The study population consists of 646 preschool teachers working in Trabzon province and town centers during 2018- 2019 academic year. The study sample consisted of 267 preschool teachers selected by cluster sampling method. The data were collected using "Art and Aesthetics Field Competence Scale". Descriptive statistical techniques were used for the analysis of the research data; t-test and one-way ANOVA were used for the comparison of the variables.

\section{Results}

In the study, preschool teachers' self-efficacy perceptions of art and aesthetics were found to be "sufficient" in the dimensions of knowledge and aesthetics, and "somewhat sufficient" in art practices. It was seen that preschool teachers' self-efficacy perceptions differed significantly in the dimension of having knowledge in relation to the visiting art exhibition variable, where there was no difference between their views in the dimensions of performing application in art and aesthetic field. Preschool teachers' self-efficacy perceptions of art and 
aesthetics values differed significantly according to the variables of having an artistic engagement, giving attention to aesthetics in evaluating student works, giving opportunities for art activities, giving attention to art and aesthetics in classroom design.

\section{Discussion and Suggestions}

Preschool teacher candidates' self-efficacy perceptions of art and aesthetics values were not high and self-efficacy perceptions were relatively low in art practices. It can be said that preschool teachers' self-efficacy perceptions about having knowledge and having aesthetic gaze are not very high and relatively low in practice due to their lack of education and lack of experience in art. Thus, Benic, Herzog \& Susic (2017) suggested that elementary and early childhood education teachers' attitudes about the importance of art and creativity in education and their perceptions of professional competence might be depending on the quality of their education. Garvis \& Pendergast (2011) stated that art content knowledge is an important source of teacher self-efficacy. Other similar studies showed that preservice teachers do not have sufficient experience in art education (Welch, 1995; Gonen, Aydos, \& Erdem, 2016; Bilir-Seyhan \& Sakire, 2018). In addition, it was understood that preschool teachers thought that the art education courses they receive in their undergraduate education were inadequate (Ozkan \& Girgin, 2014).

Preschool teachers' self-efficacy perceptions about providing artistic and aesthetic values were evaluated according to the variables such as; visiting an art exhibition, having an artistic engagement, giving attention to aesthetics in evaluating student works, giving opportunities for art activities, giving attention to art and putting aesthetics in classroom design. According to the findings, it was found that preschool teachers who mostly visited art exhibitions had higher self-efficacy perceptions in the field of acquiring art and aesthetic values. On the other hand, it was understood that preschool teachers who have an artistic engagement, give attention to aesthetics in evaluating student works, give opportunities for art activities, and give attention to art and aesthetics in classroom design were more competent in providing art and aesthetic values.

Teachers' visits to art exhibitions, engaging in art activities, evaluating students' work, giving opportunities for art activities, and attaching importance to art and aesthetics in classroom design can be considered as indicators of teachers' curiosity and interest in art. Special skills and interest of individuals can stimulate their desire to try and use those skills (Gultekin, 2011) because, 
there is a relationship between viewpoints of preschool teachers about art and aesthetics and the frequency of artistic activities (Novaković, 2015). Therefore, research found that teachers with low self-efficacy in art knowledge and skills limit their teaching of art in their classes (Garvis, 2008; Garvis \& Pendergast, 2010). Previous research also showed that adolescents who received art education got significantly higher average scores of creativities in comparison to those who did not receive art education (Aral, 1999). In addition, it has been shown that as teachers' frequency of visiting art exhibitions increases their efficacy to have knowledge about art and aesthetics (Akyildiz, 2016). On the other hand, teacher's beliefs in self-efficacy are important source of motivation for their behavior in their classrooms and subjective perceptions of teachers about their self-efficacy can affect their actual performance in art (Garvis \& Pendergast, 2011). Research indicates that there is a relationship between teachers' knowledge and skills in the field of art as well as their interest in art and self-efficacy perceptions. Similar with the previous findings of research, it is concluded that the preschool teachers' curiosity and interest in art had positive effect on teachers' high self-efficacy perceptions of providing artistic and aesthetics values.

Based on the findings of this research, following suggestions were developed to improve the self-efficacy perceptions of preschool teachers in order to provide artistic and aesthetic values.

- The content of courses related to art and aesthetics in preschool education program can be enriched and it can be ensured that prospective teachers are able to acquire skills in organizing art activities.

- Within the scope of continuous professional development, preschool teachers in the field should be encouraged by school administrators to visit art exhibits, engage in art, participate in art activities, go to art trainings etc.

- Appropriate practices of preschool teachers in the field related to art practices can be shared with other teachers.

- In preschool education, teachers' competencies and barriers related to art and aesthetics education can be determined by making more in-depth studies on art and aesthetics education of teachers. 